\title{
Implementation of Brown \& Levinson's Sociological Aspects in Verbal Interaction at Hotel Context
}

\author{
${ }^{1}$ I Made Rai Jaya Widanta, ${ }^{2}$ Made Budiarsa, ${ }^{3}$ I Wayan Simpen, ${ }^{4}$ I Made Netra \\ 1. rai_widanta@yahoo.com PNB Bukit Jimbaran St., Kuta Selatan, Badung, Bali. \\ 2.made budiarsa@yahoo.com Faculty of Arts, Udayana University \\ 3. wayan_simpen@yahoo.com Faculty of Arts, Udayana University \\ 4. made_netra@yahoo.com Faculty of Arts, Udayana University
}

\begin{abstract}
This research is an initiating reserach atempting to support the main project of developing pragmatic-based English teaching model at vocational college. Specifically, it is aimed examining whether (or not) sociocultural aspects of power, distance, and rank of imposition (PDR) proposed by Brown and Levinson (1987) is applicable for hotel context. In addition, it was aimed at designing oral role play card used for the main research data collecting. The role play card focuses on speech act (SA) of request and refusal. Twenty hotel staff were involved in doing exemplar generation, and activity undertaken to list situations at hotel dealing with request and refusal, and to inventory two most widely occured situation of each SA to be used as topic of role play card. The card was piloted by involving three students to see whether they were appropriate and obtain input of correction both content and language before being used. It was concluded that PDR is not tottaly suitable sosiological aspect used for criteria in doing verbal interaction at hotel context as power and distace (P D) are not distinctive aspects.
\end{abstract}

Key words: implementation, sociological aspects, verbal interaction, hotel context

\section{Introduction}

Sociology is one of aspects based on which speakers get in touch with hearers. Of the some sociological aspects people use, 'power', 'distance and', 'rank of imposition' or PDR (Brown and Levinson, 1987) is quite famouse. There has been a number of researach in pragmatics in which it is implemented (Kuhi, 2012 ; Lin, 2014; Taguchi, 2009; Beltran, 2004; Taguchi, 2013; Felix-Brasdefer, 2004; dan Tian, 2014). This research was aimed at testing whether or not PDR is applicable distinctively in hotel communication. Obviously, its applicabilty was examined in making speech acts of request and refusal done by hotel staff's verbal interaction with the guests.

Sociocultural aspect of PDR has been mostly used in politeness studies. During undertaking the main research project, it was used to make data collecting instrument. PDR

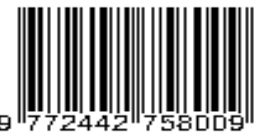


was used in developing instruemnt of oral role play card, an instrument used to collect data of request and refusal utterances made by hotel staff during their giving hospitality services. Generally, PDR is used

\section{Basic Concept of PDR and its Realitation in Hotel Context}

Brown and Levinson (1987) stated that there are three variables which influence speech acts situation, they are power (P), distance (D) and rank of imposition (R). Power (P) regulates three kinds of relations between speakers and hearer in term of hearer social status, they are hearer's higher social status, hearere's same level social status, and hearer's lower social status. Distance (D) refers to familiarity which influences language and attittude of the both parties, speakers and listenres, they are close relationship and far relationship. And rank of imposition (R) refers to level of imposition the speakers give to hearer when utter the request and refusal speech acts, they are high imposition and low imposition. For instance, in the case of request, when someone asks for someone's a necessary help, the imposition ( $\mathrm{R}$ ) will be high, coversaly, its $\mathrm{R}$ will be lower if he or she asks for a not very necessary help (Geyang, 2007). Tian (2014) stated that implementation of these strategy depend on relationship between speakers and hearers as well as utterances. The choice of certain strategies is determined by relationship between both parties and the topic. Strategies of politeness shall be high in the case of high R. However in the case of lower social distance (D), strategi of politeness will certainly be low. In the situation of $\mathrm{R}+$, a lot politeness forms or markers are hoped and vice versa. The three compositions are shown in the following figure.

Figure 1. Brown and Levinson's Sociocultural Aspect (1987)

(R) Impositon Politeness

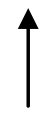

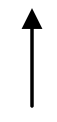

(D)

Social Distance Politeness

166

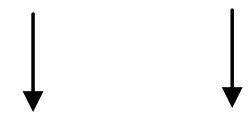




\section{(P) Power of Speaker Politeness}

\section{Research Method and Research Findings}

The reserach was done prior to the main reserach project of Developing Pragmaticbased English Learning Model at Hotel Context. The research was attempted to develop a data collecting instrument in the form of oral role play card. The role play cards consist of two main cards of request and refusal. These speech acts were chosen to be the ones utilized to investigate hotel staff competence in producing English utterances pursuant to the observation result that those SA are the most famous SA used at hotel. As request and refusal are the most widely occured SA at hospitality industry, 'exemplar generation' (Rose, 2000) was used to see the most commonly occured situation of request and refusal. Thus, around 20 staff were given a form to list ten situstions in which request and refusal happen in order of its frequency. The lists were then inventory and only the most two situations for each SA were chosen.

Role play cards were made based on the situations sucessfully listed. Based on social relationship between staff and the guests, there are absolute condition related to power $(\mathrm{P})$ and distance (D) aspect. Basically, social distance between the staff and the guest are constantly far $(+)$. It is resulted by the situation of the hotel context where staff have to give show hospitable attitude, they have certainly keep the distance far to the guests. The situations also trigger condition where power of the guests certainly become higher than the staff as the concept of "customer is king' is implemented In contrast, imposition differs as it deals with procedure and urgency. As both $\mathrm{P}$ and $\mathrm{D}$ are not distinctive in any situation in hotel context, they are not used to code the card. 
There are two types of imposition staff factually can produce, high and low impisition. Low impositive request ( $\mathrm{Rq} \mathrm{R}-)$ is a procedural request which is done based on standard operating procedure (SOP) of the hotel and high impositive request was done when there is an urgency. For instance, the staff made highly impositive request $(\mathrm{Rq} R+)$ was made when there is an unprocedural case where the staff requested the guest to check out earlier than the normal time as there are a lot of guests quing for a check out.

It can be concluded that sociocultural theory is not purely applicable, particularly in hotel context. It can be modified in accordance with the needs and situation. The modification showed that in the case of requesting guest to do things, power $(\mathrm{P})$ of the guest is absolutely stonger (+) than the staff at any situation. Distance (D) also has positive (+) mark as distance between staff and hotel guests is always far. Indistinctiveness of both aspects of sociology in hotel context bring about the situation.

In the case of request, power $(\mathrm{P}+)$ is compulsary as the guests have certanly power $(\mathrm{P}+)$. Thus, $\mathrm{P}$ is not used to be a measuring aspect. Social distance (D) also has an absolut position and not changed for any situation. Thus it is given $\mathrm{P}(+)$ as there is a far distance between staff and guest. However, rank of imposition (R) is the only aspect which is not absolute and changable. In situation of request, a staff can aske the guest to do thing in accordance with the procedure ( $\mathrm{Rq} \mathrm{R}-)$ and can ask the guests to do thing by force which is not pursuat to procedure as there is an urgent situation $(\mathrm{Rq} \mathrm{R}+)$. Thus, the formulas of those situation are $\mathrm{Rq} P+\mathrm{D}+\mathrm{R}-$ and $\mathrm{Rq} \mathrm{P}+\mathrm{D}+\mathrm{R}+$.

In the case of refusal, sociological aspects are not also fully implemented. As $\mathrm{P}$ and $\mathrm{D}$ are absolut aspects as guests power and distance is still high. Imposition (R) is not applicable totallythis aspect is not dealing with refusal. Thus, it cannot be designed to be $\mathrm{Rf}$ $\mathrm{R}+$ and Rf R-. Refusal however was designed to be Rf Terpaksa (by force) and Rf Biasa (common). The four situations can be seen in the following figure.

Figure 2. Modification of Sociological Aspect of PDR in Request and Refusal SA at Hotel Context.

$\begin{array}{llll}\text { Request } 1 & \text { Request } 2 & \text { Refusal } 1 & \text { Refusal } 2\end{array}$




$\begin{array}{llll}\mathrm{P}+ & \mathrm{P}+ & \mathrm{P}+ & \mathrm{P}+ \\ \mathrm{D}+ & \mathrm{D}+ & \mathrm{D}+ & \mathrm{D}+ \\ \mathrm{R}+ & \mathrm{R}- & \text { Biasa } & \text { Khusus }\end{array}$

The modified SA situation of request and refusal coded $\mathrm{Rq}(\mathrm{R}-) ; \mathrm{Rq}(\mathrm{R}+)$; $\mathrm{Rf}(\mathrm{B}) ; \mathrm{Rf}$ (K) can be realized in form of oral role play card as follows.

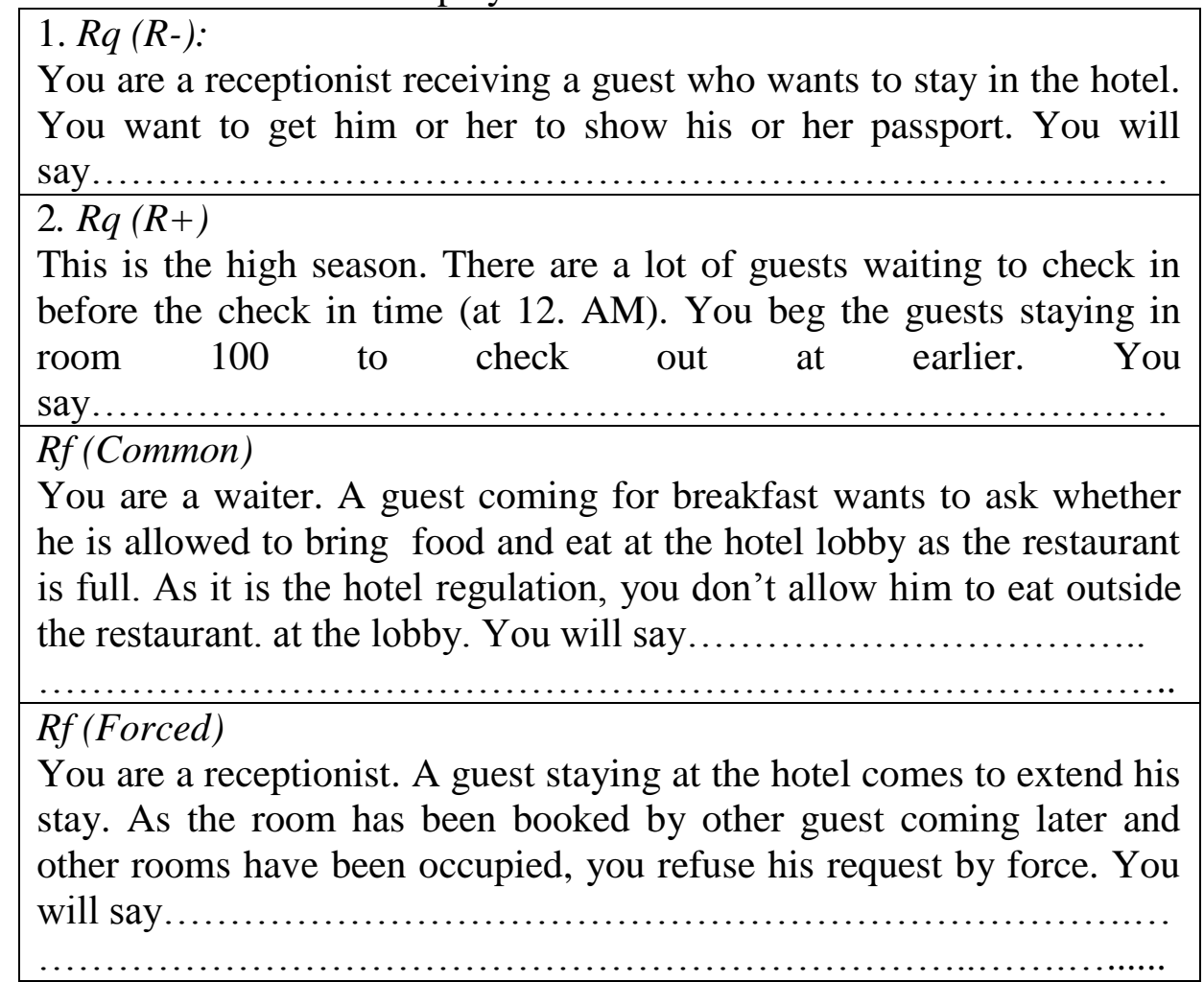

The cards were piloted by involving three college students majoring in tourism to see whether they usedable and comprehensible. In addition, it was aimed to obtain input of correction both content and language use. The cards were then used to collect data of students pragmatic competence for reserach. Twenty students were involved in data collection of students' pragmatic competence. Each reserach participant was given the four cards (Rq R-; Rq R+; Rf Common; Rf Forced). Data of request and reusal utterances from the research participants were collected, explicated and analyzed.

\section{Conclusion and Suggestion}


It could be concluded that PDR concept is less universal. It can not be used to as sociological aspect of verbal interaction in cerlain domain, like hotel. The concept is not applicable in hotel context where speakers only have lower level of power $(\mathrm{P})$ and distance (D) than hearers. These aspects of sociology are not distinctive enough to a number of situation in hotel. Apart form these aspect, rank of imposition $(\mathrm{R})$ is the only aspect that can be used to differentiate request. However, all aspects failed to affix refusal speech act.

The further investigation is to be undertaken to proove their validity. Similar research can be done using different SA, such as colpiment, apology, invitation, advice, suggestion, disagreement, complaint, or reprimend using the same context. Other context can also be used to see the sociological aspects validity, such as market, education, meeting, or others.

\section{References}

Beltrán, Elina Vilar dan Alicia Martínez-Flor (2004). “Analysing English Native Speakers' Use Of Request Modification Devices During A Role-Play Activity (a) the Spanish Ministerio de Educación y Ciencia (HUM2004-04435/FILO), co-funded by FEDER, and (b) Fundació Universitat Jaume I and Caixa Castelló-Bancaixa” (P1.1B200434).

Brown, Penelope dan Steven Levinson. 1987. Politeness: Some Universals in Language Usage. Cambridge: Cambridge university press.

Felix-Brasdefer, J. C. 2004. "Iterlanguage Refusals: Linguistic Politeness and Length of Residence in the Target Community". Language Learning 54(4): 587-653

Geyang Z. (2007). "A Pilot Study on Refusal to Suggestions in English by Japanese and Chinese EFL Learners”. Bull, Grad. School Edu. Hiroshima Univ, 56, pp.155-163. Retrieved April 16, 2007 fromhttp://ir.lib.hiroshimau.ac.jp/metadb/up/kiyo/AA11618725/ AA11618725_56_155.pdf.

Kuhi, Davud dan Mohammad Jadidi (2012). "A Study of Iranian EFL Learners' Understanding and Production of Politeness in Three Speech Acts: Request, Refusal, and Apology" ISSN 1799-2591 Theory and Practice in Language Studies, Vol. 2, No. 12, pp. 2624-2633, December 2012 (C) 2012 ACADEMY PUBLISHER Manufactured in Finland. doi:10.4304/tpls.2.12.2624-2633.

Lin, Ming-Fang, (2014). "An Interlanguage Pragmatic Study on Chinese EFL Learners Refusal: Perception and Performance". ISSN 1798-4769 Journal of Language Teaching and Research, Vol. 5, No. 3, pp. 642-653, May 2014 (C) 2014 ACADEMY PUBLISHER Manufactured in Finland. doi:10.4304/jltr.5.3.642-653. 
Rose, Kenneth, 2000. "An Exploratory Cross-sectional Study of Interlanguage Pragmatic Development". Studies in Second Language Acquisition 22, 27-67.

Taguchi, Naoko. (Ed.). (2009). Pragmatic Competence. New York, Berlin: Mouton de Gruyter.

Taguchi, Naoko. (2013). “Individual Differences and Development of Speech Act production". (Associate Professor, Carnegie Mellon University, USA) taguchi@andrew.cmu.edu, (Received: 01.05.2013, Accepted: 28.05.2013)

Tian, Xiufeng. (2014). "Investigating L2 Refusals: A Case Study of Chinese Native Speakers' L2 Pragmatic Competence”. ISSN 1799-2591. Theory and Practice in Language Studies, Vol. 4, No. 1, pp. 212-216, January 2014 (C) 2014 Academy

Publisher

Manufactured in Finland.doi:10.4304/tpls.4.1.212-216. Hebei Finance University, Baoding City, China. 